\title{
Pengaruh Stres dan Lingkungan Kerja Non Fisik terhadap Kinerja Karyawan
}

Conference Paper · June 2014

DOI: $10.13140 / R G \cdot 2 \cdot 1 \cdot 4621.5441$

CITATIONS

0

3 authors, including:

\section{Herman Sjahruddin}

Brawijaya University

28 PUBLICATIONS 15 CITATIONS

SEE PROFILE
READS

3,041

Some of the authors of this publication are also working on these related projects:

Project

Financial Banking View project

Project

Employee Performance View project 
Pengaruh Stres dan Lingkungan Kerja Non Fisik terhadap Kinerja Karyawan Pada PT. Bumi Jasa Utama (Kallatransport) Makassar (Maqfiranti, Sjahruddin dan Anto, 2014)

\title{
Pengaruh Stres dan Lingkungan Kerja Non Fisik terhadap Kinerja Karyawan
}

\author{
Vivi Maqfiranti ${ }^{1,}$ Herman Sjahruddin ${ }^{2}$, Ahmad Anto ${ }^{3}$ \\ 1,2,3 (Sekolah Tinggi Ilmu Ekonomi Makassar, STIE YPBUP Bongaya)
}

\begin{abstract}
ABSTRAK
Penelitian ini bertujuan untuk menguji dan menganalisis pengaruh stres kerja dan lingkungan kerja non fisik terhadap kinerja karyawan. Pendekatan yang digunakan dalam penelitian ini adalah pendekatan kuantitatif yang datanya berwujud pada angkaangka. Desain penelitian menggunakan survei, wawancara dan pengedaran kuesioner. Populasi dalam penelitian ini adalah seluruh karyawan tetap yaitu sebanyak 40 orang karyawan. Metode penentuan sampel dalam penelitian ini menggunakan metode sensus (sampling jenuh). Hasil pengujian hipotesis menunjukkan bukti bahwa stres kerja tidak signifikan pengaruhnya terhadap kinerja karyawan dengan nilai t-hitung sebesar 0,789 lebih kecil dari nilai t-tabel yaitu sebesar 1,688. Sedangkan untuk variabel lingkungan kerja non fisik berpengaruh secara positif dan signifikan terhadap kinerja karyawan, dimana nilai t-hitung sebesar 3,539 lebih besar dari nilai t-tabel yakni sebesar 1,688.
\end{abstract}

Kata Kunci : Stres, Lingkungan Kerja Non Fisik, Kinerja Karyawan http://dx.doi.org/

\section{Pendahuluan}

Aktivitas dalam bekerja mengandung unsur kegiatan sosial yang menghasilkan sesuatu dan pada akhirnya bertujuan untuk memenuhi kebutuhannya dan juga bertujuan untuk mencapai taraf hidup yang lebih baik, (As'ad 2004:46). Dari sisi perusahaan, aktivitas kerja karyawan merupakan salah satu penentu keberhasilan organisasi dalam menjalankan bisnisnya. Hal ini menunjukkan adanya hubungan timbal balik antara kebutuhan karyawan untuk bekerja dengan kebutuhan perusahaan akan sumber daya manusia untuk menjalankan roda organisasi dan mencapai tujuan organisasi.

Perbaikan kinerja baik untuk individu maupun kelompok menjadi pusat perhatian dalam upaya meningkatkan kinerja organisasi. Istilah kinerja berasal dari kata $J_{o b}$ Performance atau Actual Performance

(prestasi kerja atau prestasi sesungguhnya yang dicapai oleh seseorang). Pengertian kinerja merupakan hasil kerja secara kualitas dan kuantitas yang dicapai oleh seorang karyawan dalam melaksanakan tugasnya sesuai dengan tanggung jawab yang telah diberikan kepadanya (Mangkunegara, 2006). Kinerja pada dasarnya adalah apa yang dilakukan atau tidak dilakukan karyawan sehingga mempengaruhi seberapa banyak mereka memberi kontribusi kepada instansi atau organisasi termasuk kualitas pelayanan yang disajikan. Pada umumnya kinerja diberi batasan sebagai kesuksesan seseorang dalam melaksanakan suatu pekerjaan. (Bernardin dan Russel, 2006).

Penjelasan teori kinerja yang dikemukakan oleh Robbins (2006) menyatakan bahwa kinerja 
merupakan fungsi interaksi antara kemampuan atau ability $(A)$, motivasi atau motivation $(M)$ dan kesempatan atau opportunity $(O)$, yaitu kinerja $=$ $\mathrm{F}$ (A $\mathrm{x}$ M X O), artinya kinerja merupakan fungsi dari kemampuan, motivasi dan kesempatan.

Pekerjaan selalu membawa konsekuensi yang berbeda, dampak yang ditimbulkan dari pekerjaan ada yang positif dan ada yang negatif. Dampak positif dari pekerjaan yang dilakukan antara lain adalah kepuasan kerja, sedangkan dampak negatif yang ditimbulkan dari suatu pekerjaan adalah beban kerja yang menyebabkan terjadinya stres. Perkembangan ilmu pengetahuan dan teknologi yang sangat pesat, akan membawa perubahan dalam kehidupan manusia. Perubahan tersebut membawa akibat berupa tuntutan yang lebih tinggi terhadap setiap individu untuk lebih meningkatkan kinerja mereka sendiri. Setiap individu mengalami stres terutama individu yang kurang dapat menyesuaikan dirinya dengan perkembangan tersebut (Mardiana dan Muafi, 2004).

Stres adalah kondisi ketegangan yang mempengaruhi emosi, proses berpikir sehingga menjadi gugup, merasakan kekhawatiran kronis, mudah marah, agresif dan tidak dapat rileks (Hasibuan, 2003:203). Tinggi rendahnya kinerja karyawan sangat dipengaruhi oleh tingkat stres yang dimiliki karyawan tersebut. Stres mempunyai dampak yang positif dan negatif, dampak positif stres pada tingkat rendah sampai pada tingkat moderat bersifat fungsional dalam arti berperan sebagai pendorong peningkatan kinerja karyawan, untuk dampak negatif menyebabkan stres pada tingkat yang tinggi diperlihatkan melalui penurunan kinerja karyawan yang drastis (Sasono, 2004:5).

Faktor-faktor yang mempengaruhi stres berdasarkan pendapat dari beberapa ahli, diantaranya menyebutkan bahwa stres kerja dipengaruhi oleh faktor eksternal (meliputi faktor lingkungan fisik berupa pencahayaan ruang yang kurang, ventilasi yang kurang serta jadwal tugas yang berlebihan, dan faktor fisiologis seperti permintaan peran atau aturan pekerjaan) dan faktor internal (yang berasal dari dalam diri karyawan itu sendiri), (Davisson, 1990; dalam Analisa, 2011:20). Pandangan lain terhadap faktor yang mempegaruhi tingkat stres individu, bersumber dari: (1) konflik kerja, (2) beban kerja, (3) waktu kerja, (4) karakteristik tugas, dan (5) dukungan kelompok, serta (6) pengaruh kepemimpinan, (Andraeni Novitasari, 2005).

Pengaruh positif terhadap kinerja individu (karyawan) ditunjukkan melalui lingkungan kerja. Lingkungan kerja adalah segala sesuatu yang ada disekitar para karyawan/pekerja yang dapat mempengaruhi dirinya dalam menjalankan tugas yang dibebankan (Nitisemito, 1996; dalam Hertanto, 2011:5)

Bukti empiris yang menunjukkan adanya inkonsistensi temuan penelitian dalam menganalisis kinerja karyawan yang dipengaruhi stres kerja ditunjukkan dalam penelitian yang dilakukan oleh Sutrisno (2009) bahwa stres kerja berpengaruh secara signifikan terhadap kinerja karyawan, artinya bahwa semakin tinggi stres kerja 
yang dialami, maka semakin meningkat kinerja karyawan. Bukti penelitian tersebut didukung dengan temuan penelitian Abdullah (2012) bahwa terdapat pengaruh yang signifikan antara stres kerja dengan kinerja karyawan. Hasil penelitian yang dikemukakan kedua peneliti tersebut (Sutrisno, 2009; dan Abdullah, 2012) ditolak atau tidak didukung oleh Nur, Saina (2013) yang menganalisis Pengaruh Konflik, Stres Kerja dan Kepuasan Kerja terhadap Kinerja Pegawai Pada Universitas Khairun Ternate, hasil penelitiannya mengemukakan bukti bahwa stres kerja tidak signifikan pengaruhnya terhadap kinerja pegawai (karyawan).

Variabel yang mempengaruhi kinerja selain stres kerja dalam penelitian ini adalah lingkungan kerja, hasil penelitian yang dilakukan oleh (Yusianto, 2008) menunjukkan bahwa lingkungan fisik yang merupakan dimensi (indikator) dari variabel stres kerja berpengaruh signifikan terhadap prestasi kerja staf (kinerja pegawai). Temuan penelitian tersebut memiliki kesamaan dengan penelitian yang dilakukan (Primayanti, 2013) bahwa lingkungan kerja karyawan berpengaruh signifikan terhadap kinerja karyawan.

Berdasarkan hubungan antar variabel tersebut (stres kerja dan

\section{TINJAUAN PUSTAKA}

2.1. Stres Kerja

Tinggi rendahnya kinerja karyawan sangat dipengaruhi tingkat stres yang dimiliki karyawan tersebut. Stres kerja merupakan suatu kondisi ketegangan yang mempengaruhi emosi, proses berpikir dan kondisi seseorang, lingkungan kerja, pengaruhnya terhadap kinerja karyawan) ditemukan masih terdapatnya inkonsistensi temuan dari penelitian terdahulu tersebut, maka penelitian ini bertujuan untuk menganalisis dan menguji kembali pengaruh dari masing-masing variabel (stres kerja dan lingkungan kerja terhadap kinerja karyawan).

Penelitian ini dilakukan pada PT. Bumi Jasa Utama (Kallatransport) yang merupakan perusahaan yang bergerak di bidang jasa rental kendaraan, jasa rental kendaraan ditawarkannya kepada perusahaan-perusahaan dan orang pribadi. Pencapaian kinerja karyawannya dicerminkan melalui pendapatan yang diperoleh perusahaan menunjukkan bahwa persentase pendapatan perusahaan pada tahun 2010-2011 perubahan pendapatan perusahaan sebesar 6,93\%, kemudian untuk tahun 2011-2012 terjadi penurunan perubahan sebesar $4,27 \%$ (menurun), dan di tahun 2012-2013 sebesar $5,47 \%$ (persentase kenaikan rendah), berdasarkan data tersebut maka dapat dinyatakan bahwa pendapatan perusahaan (kinerja) mengalami perubahan yang berarti, kondisi tersebut mendasari penelitian ini untuk menganalisis kinerja karyawan sebagai cerminan dari kinerja perusahaan.

tingkat stres yang tinggi dapat mempengaruhi kemampuan seseorang untuk menghadapi lingkungan kerjanya dan pada akhirnya mengganggu pelaksanaan tugas-tugasnya sehingga berdampak negatif terhadap prestasi kerjanya atau kinerjanya, (Handoko 2008). 
Stres adalah kondisi ketegangan yang mempengaruhi emosi, proses berpikir sehingga menjadi gugup, merasakan kekhawatiran kronis, mudah marah, agresif dan tidak dapat rileks (Hasibuan, 2003:203).

Pendapat lain menyatakan bahwa stres kerja terjadi jika seseorang tidak dapat memenuhi tuntutan atau kebutuhan dari pekerjaannya (Losyik, 2007:4). Individu pada umumnya menganggap bahwa stres merupakan suatu kondisi yang mengarah kepada timbulnya penyakit fisik maupun mental atau mengarah ke perilaku yang tidak wajar (distress). Akibat lain yang ditimbulkan stres yang bersifat positif disebut sebagai eustress yang merupakan kekuatan yang positif dimana stres kadangkala dapat diperlukan untuk menghasilkan prestasi yang tinggi. (Selye, 1976; dalam Munandar, 2008:378). Cerminan dalam mengetahui tingkat stres yang dialami individu (karyawan) dalam bekerja dapat dilihat berdasarkan pada beberapa indikator yaitu : (1) Konflik kerja, (2) Beban kerja, (3) Waktu kerja, (4) Karakteristik tugas, (5) Dukungan kelompok, dan (6) Pengaruh kepemimpinan (Andraeni Novitasari, 2005:64).

Bukti empiris menunjukkan bahwa terdapat pengaruh yang signifikan antara stres kerja terhadap kinerja karyawan ditunjukkan pada studi yang dilakukan Sutrisno (2009) dan bertujuan untuk menganalisis pengaruh stres kerja terhadap kinerja karyawan dengan menggunakan 75 orang karyawan sebagai populasi sekaligus menjadi sampel dalam penelitian tersebut (sensus/jenuh). Pengujian hipotesis dilakukan dengan menggunakan analisis regresi linear berganda melalui SPSS program sebagai alat bantu dalam menguji hipotesis yang diajukan. Hasil penelitiannya menunjukkan bahwa ada pengaruh yang signifikan antara stres kerja terhadap kinerja karyawan.

Temuan tersebut didukung dengan temuan Abdullah (2012) yang bertujuan untuk menganalisis pengaruh stres kerja terhadap kinerja auditor, dengan menggunakan 42 auditor sebagai populasi sekaligus menjadi sampel dalam penelitian tersebut (sensus/jenuh). Pengujian hipotesis dilakukan dengan menggunakan analisis regresi linear berganda melalui SPSS program dalam menguji hipotesis yang diajukan. Hasil penelitiannya menunjukkan bahwa ada pengaruh yang signifikan antara stres kerja terhadap kinerja auditor.

\subsection{Lingkungan Kerja}

Lingkungan kerja adalah segala sesuatu yang ada disekitar karyawan dan yang dapat mempengaruhi dirinya dalam menjalankan tugas-tugasnya. (Nitisemito, 1996; dalam Hertanto, 2011:5). Secara garis besar, berdasarkan jenisnya lingkungan kerja dapat dikelompokkan kedalam 2 (dua) jenis pengelompokkan (Sedarmayanti, 2001; dalam Analisa, 2011:21) yaitu :

(1) Lingkungan kerja fisik yaitu seluruh keadaan berbentuk fisik yang terdapat di sekitar tempat kerja yang dapat mempengaruhi karyawan baik secara langsung maupun secara tidak langsung. Lingkungan 
kerja fisik sebagai keseluruhan atau setiap aspek dari gejala fisik dan sosial-kultural yang mengelilingi atau mempengaruhi individu (Komarudin, 2002; dalam Analisa, 2011:21). Lingkungan kerja fisik mempunyai dampak positif dan negatif terhadap karyawan, dampak positif dan negatif dipengaruhi oleh beberapa faktor (Analisa, 2011:22), yaitu : Pewarnaan, penerangan, udara, suara yang bising, ruang gerak, keamanan dan kebersihan

(2) Lingkungan kerja non fisik berkaitan dengan seluruh keadaan yang terjadi dengan hubungan kerja, baik hubungan dengan atasan maupun hubungan dengan bawahan sesama rekan kerja. Lingkungan kerja non fisik ini tidak kalah pentingnya dengan lingkungan kerja fisik. (Sedarmayanti, 2001; dalam Analisa, 2011:25). Semangat dan kegairahan kerja karyawan sangat dipengaruhi oleh keadaan lingkungan kerja non fisik, misalnya hubungan dengan sesama karyawan dan dengan pimpinan. Jika hubungan karyawan dengan karyawan lainnya serta dengan pimpinan berjalan dengan baik maka dapat membuat karyawan merasa lebih nyaman berada di lingkungan kerjanya.Terdapat lima aspek lingkungan kerja non fisik yang bisa mempengaruhi perilaku karyawan (Analisa, 2011:25) yaitu : Struktur kerja, Tanggung jawab kerja, Perhatian dan dukungan pemimpin, Kerjasama antar kelompok dan Kelancaran komunikasi.

Indikator yang digunakan dalam menganalisis lingkungan kerja non fisik, ditunjukkan melalui, suasana kerja dan hubungan kerja serta fasilitas kerja (Nitisemito, 1982; dalam Septianto, 2010:31)

Hasil penelitian Yusianto (2008) yang bertujuan untuk menganalisis pengaruh stres kerja terhadap prestasi kerja staf dengan menggunakan 40 staf sebagai sampel dalam penelitian tersebut. Pengujian hipotesis dilakukan dengan menggunakan analisis regresi linear berganda Hasil penelitiannya menunjukkan bahwa stres lingkungan fisik memiliki pengaruh terhadap kinerja staf pengajar. Temuan tersebut didukung dengan hasil penelitian yang dilakukan Primayanti (2013) yang bertujuan untuk menganalisis pengaruh stres kerja dan lingkungan kerja terhadap kinerja karyawan dengan menggunakan 40 orang karyawan sebagai populasi sekaligus menjadi sampel dalam penelitian tersebut (sensus/jenuh). Pengujian hipotesis dilakukan dengan menggunakan analisis regresi linear. Hasil penelitiannya menunjukkan bahwa stres kerja dan lingkungan kerja berpengaruh signifikan terhadap kinerja karyawan. 
2.3. Kinerja Karyawan

Kinerja adalah hasil kerja

baik secara kualitas maupun

kuantitas yang dihasilkan oleh seseorang karyawan dalam periode tertentu sesuai dengan tanggung jawab yang diberikan (Hasan, 2012). Kinerja pada dasarnya adalah apa yang dilakukan atau tidak dilakukan karyawan sehingga mereka mempengaruhi seberapa banyak mereka memberi kontribusi kepada instansi atau organisasi termasuk kualitas pelayanan yang disajikan. Pada umumnya kinerja diberi batasan sebagai kesuksesan seseorang di dalam melaksanakan suatu pekerjaan. Kinerja meruapakan catatan out come yang dihasilkan dari fungsi karyawan tertentu atau kegiatan yang dilakukan selama periode waktu tertentu (Bernardin dan Russel; dalam Sutrisno, 2009).

\section{METODE PENELITIAN}

Penelitian ini menggunakan pendekatan kuantitatif yang datanya berwujud pada bilangan (angkaangka) dan pembuktian hipotesis yang dilakukan menggunakan analisis statistik (Sugiyono, 2011:15). Populasi dalam penelitian ini adalah seluruh karyawan yang bekerja pada PT. Bumi Jasa Utama

\section{HASIL PENELITIAN}

4.1. Uji Instrument

Instrument dikatakan valid akan mempunyai arti bahwa angket mampu mengukur apa yang seharusnya diukur. Untuk mengukur validitas digunakan korelasi product moment pearson diatas dari 0,30 pada taraf signifikansi 0.05. Uji reliabilitas digunakan untuk mengukur instrumen penelitian pada obyek yang sama dan akan menghasilkan data yang sama (konsisten),
Kinerja karyawan dapat diukur melalui ; Kualitas, Kuantitas, Kreativitas dan Pengetahuan kerja (Gomes, 1993; dalam Septianto, 2010:26).

Inkonsistensi temuan dari peneliti terdahulu dalam menganalisis pengaruh lingkungan kerja dan stres kerja terhadap kinerja karyawan ditunjukkan dalam penelitian Nur, Saina (2013) yang bertujuan untuk menganalisis pengaruh stres kerja terhadap kinerja pegawai dengan menggunakan 105 pegawai sebagai sampel dalam penelitian tersebut. Pengujian hipotesis dilakukan dengan menggunakan analisis jalur (path analysis) melalui pemanfaatan Listrel sebagai alat bantu dalam menguji hipotesis yang diajukan. Hasil penelitiannya menunjukkan bahwa stres kerja berpengaruh negatif terhadap kinerja pegawai.

(Kallatransport), berdasarkan pengamatan yang telah dilakukan terdapat sebanyak 40 orang karyawan. Mengingat karena populasi dalam penelitian skripsi ini jumlahnya terbatas maka metode penentuan sampel menggunakan metode sensus.

(Sugiyono, 2011:147). Pengujian reliabilitas dalam penelitian ini dilakukan dengan menghitung besarnya nilai Cronbach's Alpha instrumen dari masing-masing lima dimensi yang diuji. Apabila nilai cronbach coefficient alpha lebih besar dari 0,60 maka jawaban dari para responden pada kuesioner sebagai alat pengukur dinilai atau dinyatakan reliabel. 
a. Uji Validitas

1) Pengujian Validitas Variabel Stres Kerja $\left(\mathrm{X}_{1}\right)$

Tabel I. Uji Validitas Variabel Stres Kerja

\begin{tabular}{|c|c|c|c|c|}
\hline Indikator Penelitian & $\begin{array}{l}\text { Item } \\
\text { (Butir) }\end{array}$ & $\begin{array}{c}\text { Koefisien } \\
\text { Korelasi }(r)\end{array}$ & $\begin{array}{c}\text { Cronbach's } \\
\text { Alpha }\end{array}$ & Sig. \\
\hline Konflik Kerja & $\begin{array}{l}\mathrm{X}_{111} \\
\mathrm{X}_{112}\end{array}$ & $\begin{array}{l}0,903 \\
0,813\end{array}$ & 0,632 & $\begin{array}{l}0,000 \\
0,000\end{array}$ \\
\hline Beban Kerja & $\begin{array}{l}\mathrm{X}_{121} \\
\mathrm{X}_{122}\end{array}$ & $\begin{array}{l}0,835 \\
0,882\end{array}$ & 0,640 & $\begin{array}{l}0,000 \\
0,000\end{array}$ \\
\hline Waktu Kerja & $\begin{array}{l}\mathrm{X}_{131} \\
\mathrm{X}_{132}\end{array}$ & $\begin{array}{l}0,863 \\
0,835\end{array}$ & 0,612 & $\begin{array}{l}0,000 \\
0,000\end{array}$ \\
\hline Karakteristik Tugas & $\begin{array}{l}\mathrm{X}_{141} \\
\mathrm{X}_{141}\end{array}$ & $\begin{array}{l}0,875 \\
0,850\end{array}$ & 0,654 & $\begin{array}{l}0,000 \\
0,000\end{array}$ \\
\hline Struktur Kerja & $\begin{array}{l}\mathrm{X}_{211} \\
\mathrm{X}_{212}\end{array}$ & $\begin{array}{l}0,872 \\
0,835\end{array}$ & 0,625 & $\begin{array}{l}0,000 \\
0,000\end{array}$ \\
\hline Tanggung Jawab Kerja & $\begin{array}{l}\mathrm{X}_{221} \\
\mathrm{X}_{222}\end{array}$ & $\begin{array}{l}0,869 \\
0,840\end{array}$ & 0,630 & $\begin{array}{l}0,000 \\
0,000\end{array}$ \\
\hline $\begin{array}{l}\text { Pengaruh dan } \\
\text { Dukungan Pemimpin }\end{array}$ & $\begin{array}{l}\mathrm{X}_{231} \\
\mathrm{X}_{232}\end{array}$ & $\begin{array}{l}0,926 \\
0,926\end{array}$ & 0,834 & $\begin{array}{l}0,000 \\
0,000\end{array}$ \\
\hline $\begin{array}{l}\text { Kerjasama Antar } \\
\text { Kelompok }\end{array}$ & $\begin{array}{l}\mathrm{X}_{241} \\
\mathrm{X}_{242}\end{array}$ & $\begin{array}{l}0,913 \\
0,803\end{array}$ & 0,627 & $\begin{array}{l}0,000 \\
0,000\end{array}$ \\
\hline Kelancaran Komunikasi & $\begin{array}{l}\mathrm{X}_{251} \\
\mathrm{X}_{252}\end{array}$ & $\begin{array}{l}0,831 \\
0,875\end{array}$ & 0,623 & $\begin{array}{l}0,000 \\
0,000\end{array}$ \\
\hline Kualitas Kerja & $\begin{array}{l}\mathrm{Y}_{111} \\
\mathrm{Y}_{112}\end{array}$ & $\begin{array}{l}0,844 \\
0,861\end{array}$ & 0,625 & $\begin{array}{l}0,000 \\
0,000\end{array}$ \\
\hline Kuantitas Kerja & $\begin{array}{l}\mathrm{Y}_{121} \\
\mathrm{Y}_{122}\end{array}$ & $\begin{array}{l}0,890 \\
0,831\end{array}$ & 0,644 & $\begin{array}{l}0,000 \\
0,000\end{array}$ \\
\hline Kreativitas Kerja & $\begin{array}{l}\mathrm{Y}_{131} \\
\mathrm{Y}_{132}\end{array}$ & $\begin{array}{l}0,922 \\
0,936\end{array}$ & 0,840 & $\begin{array}{l}0,000 \\
0,000\end{array}$ \\
\hline Pengetahuan Kerja & $\begin{array}{l}Y_{141} \\
Y_{142}\end{array}$ & $\begin{array}{l}0,822 \\
0,876\end{array}$ & 0,611 & $\begin{array}{l}0,000 \\
0,000\end{array}$ \\
\hline
\end{tabular}

Sumber : Data diolah (2014)

Tabel I. menunjukkan bahwa seluruh indikator variabel stres kerja, lingkungan kerja non fisik dan kinerja karyawan menunjukkan nilai koefisien korelasi diatas dari 0,30 atau 30\%. menunjukkan nilai Cronbach Alpha (a) lebih besar dari o,60 maka indikator atau instrumen kuesioner adalah reliabel atau dapat dipercaya sebagai alat ukur variabel dan ayak digunakan untuk mengukur stres kerja, lingkungan kerja non fisik dan kinerja karyawan.

\subsection{Uji Asumsi Klasik}

Uji asumsi klasik adalah persyaratan statistik yang harus dipenuhi pada analisis regresi berganda, uji asumsi klasik yang digunakan dalam penelitian ini 
meliputi uji normalitas dan uji multikolinearitas.

b. Uji Normalitas

Uji normalitas dilakukan

untuk menguji apakah dalam model regresi variabel pengganggu atau residual memiliki distribusi normal. Untuk mengujinya dilakukan dengan uji statistik non parametric Kolmogorov-Smirnov (Sugiyono,

Tabel II. Hasil Uji Normalitas
2011). Variabel tersebut terdistribusi normal, apabila nilai KolmogorovSmirnov dan Unstandardized Residual Asymp. Sig (2-tailed) > 0,05, berarti lolos uji normalitas sebaliknya apabila Kolmogorov-Smirnov dan Unstandardized Residual Asymp. Sig $(2-$ tailed $) \leq 0,05$ berarti tidak memenuhi uji normalitas.

One-Sample Kolmogorov-Smirnov Test

\begin{tabular}{|c|c|c|}
\hline & & $\begin{array}{c}\text { Unstandardized Predicted } \\
\text { Value }\end{array}$ \\
\hline $\mathrm{N}$ & & 37 \\
\hline Nomml Donmentonab & Mean & 3,9078378 \\
\hline Nommat i aramecters, & Std. Deviation & ,28681563 \\
\hline & Absolute &, 133 \\
\hline Most Extreme Differences & Positive & ,060 \\
\hline & Negative &,- 133 \\
\hline Kolmogorov-Smirnov Z & & ,808 \\
\hline Asymp. Sig. (2-tailed) & &, 531 \\
\hline
\end{tabular}

a. Test distribution is Normal.

b. Calculated from data.

Sumber : Output SPSS (diolah, 2014)

Tabel II. menunjukkan bahwa output uji normalitas Kolmogorov-Smirnov diperoleh hasil bahwa nilai signifikansi sebesar 0,53 lebih besar dari 0,05, sehingga dapat disimpulkan bahwa pengaruh stres kerja dan lingkungan kerja non fisik terhadap kinerja karyawan datanya berdistribusi secara normal.

$$
\begin{aligned}
& \text { c. Uji Multikolinearitas } \\
& \text { Uji Multikolinearitas }
\end{aligned}
$$
mempunyai tujuan ditemukannya adanya korelasi antar variabel independen. Jika terjadi korelasi, maka dinamakan terdapat problem multikolinearitas. Model regresi yang baik seharusnya tidak terjadi multikolinearitas di antara variabel independen. Multikolinieritas dapat deteksi dari nilai Tolerance dan nilai VIF. Jika nilai Tolerance variabel bebas $>0,10$ dan nilai $\mathrm{VIF}<10$, maka tidak terjadi multikolinearitas; sebaliknya apabila jika nilai Tolerance $<0,10$ dan nilai VIF $>10$ maka terjadi multikolinearitas (Imam Ghozali, 2004: 91) 
Tabel III. Hasil Uji Multikolinearitas

\begin{tabular}{|ll|cr|}
\hline \multirow{2}{*}{ Model } & \multicolumn{2}{|c|}{ Collinearity Statistics } \\
\cline { 3 - 4 } & (Constant) & \multicolumn{2}{|c|}{ VIF } \\
\hline \multirow{3}{*}{1} & Stres Kerja &, 993 & 1,007 \\
& LKNF &, 993 & 1,007 \\
\hline
\end{tabular}

Sumber : Output SPSS (diolah, 2014)

Berdasarkan Tabel III. dapat disimpulkan bahwa tidak terjadi multikolinearitas karena memiliki nilai VIF sebesar $1,007<10$, dan nilai Tolerance sebesar $0,993>0,1$ maka dapat dinyatakan bahwa tidak terdapat masalah multikolinearitas pada variabel yang digunakan. Untuk menjawab hipotesis dilakukan analisis regresi linear berganda, untuk mengetahui pengaruh Stres kerja $\left(\mathrm{X}_{1}\right)$ dan Lingkungan kerja non fisik $\left(\mathrm{X}_{2}\right)$ terhadap Kinerja karyawan (Y).

\subsection{Kausalitas antar variabel}

a. Pengaruh Stres Kerja
terhadap
Karyawan
Stres kerja menurut
tanggapan responden merupakan kondisi yang membuatnya menjadi tegang sehingga mempengaruhi emosi, proses berpikir dan kondisi responden dalam bekerja. Tinggi rendahnya stres kerja karyawan dipengaruhi oleh; (1) Konflik kerja, (2) Beban kerja, (3) Waktu kerja, dan (4) Karakteristik tugas.

$$
\text { Hasil uji t (uji parsial) }
$$
pada Tabel IV. menunjukkan bahwa t-hitung $>$ t-tabel ; dimana nilai thitung untuk variabel stres kerja $\left(\mathrm{X}_{1}\right)$ sebesar 0,790 sedangkan nilai ttabel sebesar 1,688, maka dapat dinyatakan bahwa penelitian ini menolak bahwa stres kerja berpengaruh signifikan terhadap kinerja karyawan dan menerima bahwa secara parsiall variabel stres kerja tidak signifikan pengaruhnya terhadap kinerja karyawan. Faktor yang menyebabkan tidak signifikannya hasil tersebut, bahwa indikator konflik kerja memiliki nilai rata-rata terendah 5,41 dalam menjelaskan variabel stres kerja, kemudian diikuti oleh indikator beban kerja dengan nilai rata-rata sebesar 5,73, selanjutnya indikator waktu kerja nilai rata-ratanya 6,05 , dan indikator terakhir yang memiliki nilai rata-rata tertinggi dibandingkan dengan tiga indikator pengukuran lainnya adalah indikator karakteristik tugas dengan nilai rata-rata sebesar 6,14 .

Pada penelitian ini, faktor yang mendasari tidak signifikannya pengaruh Stres kerja terhadap Kinerja karyawan menunjukkan bahwa t-hitung > t-tabel; dimana nilai t-hitung untuk variabel stres kerja $\left(\mathrm{X}_{1}\right)$ sebesar 0,790 sedangkan nilai t-tabel sebesar 1,688, maka dapat dinyatakan bahwa Stres kerja tidak signifikan pengaruhnya terhadap kinerja karyawan PT. Bumi Jasa Utama (Kallatransport) Makassar.

Hasil penelitian tersebut mendukung hasil penelitian yang dilakukan oleh Nur, Saina (2013), Faktor yang mendasari tidak signifikannya variabel stres kerja terhadap kinerja pegawai pada 
penelitian yang dilakukan Nur, Saina (2013) disebabkan karena secara parsial pengaruh Stres kerja terhadap Kinerja Pegawai ditunjukkan melalui koefisien jalur pyx 1 yaitu sebesar $-0,543$, dan hasil perhitungannya diperoleh t-hitung sebesar -6,69. Dari hasil uji empiris menyatakan bahwa $\mathrm{H}_{0}$ ditolak atau dengan kata lain menerima $\mathrm{H}_{1}$. $\mathrm{Hal}$ ini disebabkan karena nilai t-hitung $=-6,63>$ t-tabel $=1,93$, sehingga dapat disimpulkan bahwa terdapat pengaruh negatif Stres kerja terhadap Kinerja Pegawai.

Hasil penelitian ini berbeda dengan temuan penelitian yang ditunjukkan oleh Sutrisno (2009) bahwa stres kerja berpengaruh secara signifikan terhadap kinerja karyawan, artinya bahwa semakin tinggi stres kerja yang dialami, maka semakin meningkat kinerja karyawan. Temuan tersebut dibuktikan dari nilai $\mathrm{t}=2,731$ pada taraf sig. = 0,008. Artinya bahwa Stres kerja dapat dijadikan sebagai dasar untuk memprediksi Kinerja karyawan.

\section{b. Pengaruh Lingkungan Kerja Non Fisik terhadap Kinerja Karyawan}

Lingkungan kerja non
fisik merupakan tanggapan responden berkaitan dengan hubungan kerja, baik hubungan dengan atasan maupun hubungan dengan bawahan sesama rekan kerja. Baik buruknya lingkungan kerja dalam suatu perusahaan dipengaruhi oleh; (1) Struktur kerja, (2) Tanggung jawab kerja, (3) Perhatian dan dukungan pemimpin, Kerjasama antar kelompok, dan (5) Kelancaran komunikasi.
Hasil uji t (uji parsial) menunjukkan bahwa pengaruh stres kerja terhadap kinerja karyawan, pada tabel tersebut, juga ditunjukkan pengaruh secara parsial lingkungan kerja non fisik $\left(\mathrm{X}_{2}\right)$ terhadap kinerja karyawan, thitung $>$ t-tabel dimana nilai thitung untuk variabel lingkungan kerja non fisik sebesar 3,539 sedangkan nilai t-tabel yakni sebesar 1,688, maka dapat dinyatakan bahwa penelitian ini menerima bahwa secara parsial lingkungan kerja non fisik berpengaruh secara positif dan signifikan terhadap kinerja karyawan.

Faktor yang mempengaruhi signifikannya hasil tersebut, bahwa indikator kerjasama antar kelompok memiliki nilai ratarata terendah sebesar 6,70, dalam menjelaskan variabel lingkungan kerja non fisik, kemudian indikator struktur kerja yakni sebesar 6,95, selanjutnya indikator pengaruh dan dukungan pemimpin memiliki nilai rata-rata 7,43, dan indikator kelancaran komunikasi dengan nilai rata-rata sebesar 8,00, serta indikator terakhir yang memiliki nilai rata-rata tertinggi dibandingkan dengan empat indikator pengukuran lainnya adalah indikator tanggung jawab kerja dengan nilai rata-rata sebesar 8,32.

Nilai rata-rata tertinggi $3,5)$ indikator variabel kerjasama antar kelompok disebabkan karena kebersediaan rekan kerja untuk bersedia membantu dalam menyelesaikan pekerjaan, sedangkan nilai rata-rata terendah untuk indikator kerjasama antar kelompok yaitu sebesar 3,16, hal ini disebabkan karena kesulitan yang dialami oleh karyawan dalam menyelesaikan 
pekerjaannya terpecahkan dengan adanya bantuan dari kelompok lain.

$$
\text { Hasil penelitian ini }
$$

mendukung hasil penelitian yang dilakukan oleh Primayanti, (2013) bahwa lingkungan kerja karyawan berpengaruh signifikan terhadap kinerja karyawan. Temuan penelitian tersebut mendukung penelitian yang dilakukan Yusianto (2008) bahwa lingkungan fisik yang merupakan dimensi (indikator) dari variabel stres kerja berpengaruh signifikan terhadap prestasi kerja staf (kinerja pegawai).

Tabel IV. Hasil Analisis Regresi Linier Berganda

\begin{tabular}{lccc}
\hline \multicolumn{1}{c}{ Variabel Penelitian } & Koefisien Regresi & thitung & Sig. \\
\hline Konstanta & 1,604 & 2,300 & 0,027 \\
Stres Kerja & 0,092 & 0,789 & 0,435 \\
Lingkungan kerja N-Fisik & 0,434 & 3,539 & 0,001 \\
Adjusted R Square = 0,230 & & \multicolumn{2}{c}{ Sig $=0,004^{\mathrm{b}}$} \\
& & \multicolumn{2}{c}{ Fitung $^{=}=6,392$} \\
\hline
\end{tabular}

Sumber : Output SPSS (diolah, 2014)

\section{KESIMPULAN}

Stres Kerja tidak signifikan pengaruhnya terhadap kinerja karyawan, hal ini disebabkan karena beberapa faktor yaitu dapat dilihat dari tanggapan responden yang menunjukkan indikator karakteristik tugas memiliki nilai rata-rata tertinggi dan untuk indikator konflik kerja memiliki nilai rata-rata terendah. Dengan demikian, hasil pengujian hipotesis membuktikan bahwa nilai t-hitung untuk variabel stres kerja $\left(\mathrm{X}_{1}\right)$ sebesar 0,789 sedangkan nilai t-tabel sebesar 1,688, maka dapat dinyatakan bahwa penelitian ini menolak bahwa stres kerja berpengaruh signifikan terhadap kinerja karyawan dan menerima bahwa variabel stres kerja tidak signifikan pengaruhnya terhadap kinerja karyawan.

Lingkungan kerja berpengaruh secara positif dan signifikan terhadap kinerja karyawan. Hal ini disebabkan karena beberapa faktor yaitu dapat dilihat dari tanggapan responden yang menunjukkan indikator tanggung jawab kerja memiliki nilai rata-rata tertinggi dan untuk indikator kerjasama antar kelompok memiliki nilai rata-rata terendah. Dengan demikian, hasil pengujian hipotesis menunjukkan nilai t-hitung untuk variabel lingkungan kerja non fisik sebesar 3,539 sedangkan nilai t-tabel yakni sebesar 1,688, maka dapat dinyatakan bahwa penelitian ini menerima bahwa lingkungan kerja non fisik berpengaruh secara positif dan signifikan terhadap kinerja karyawan. Pembentukan variabel stres kerja didominasi oleh indikator karakteristik tugas dan untuk variabel lingkungan kerja non fisik didominasi oleh indikator tanggung jawab kerja.

Upaya yang dapat dilakukan oleh perusahaan dalam menekan tingginya stres kerja, dapat dilakukan dengan cara menyesuaikan pekerjaan karyawan dengan karakteristik tugas karyawan. Dan untuk menghindari terjadinya stres kerja dalam diri karyawan maka pihak manajemen 
perusahaan, perlu untuk mengidentifikasi dan mengawasi faktor-faktor yang dapat menimbulkan terjadinya konflik kerja baik itu antar sesama karyawan maupun dengan atasan. Perbaikan lingkungan kerja, dapat dilakukan dengan cara memberikan kepercayaan kepada karyawan agar dapat bertanggung jawab atas pekerjaan yang diberikan kepadanya. Dan untuk menghindari terjadinya kesalahpahaman antar sesama karyawan, maka pihak manajemen

\section{DAFTAR PUSTAKA}

Abdullah, Zainuddin, (2012). Pengaruh Stres Kerja terhadap Kinerja Auditor melalui Motivasi Kerja Sebagai Variabel Intervening Studi Pada Auditor Intern di Pemerintah Provinsi Aceh. Jurnal Akuntansi. 2 (1). 142150 .

Analisa Permatasari, (2011). Pengaruh Lingkungan Kerja dan Kepuasan Kerja Terhadap Kinerja Karyawan Pada PT. Octa Putrajaya Tekstil Mills. Fakultas Kesehatan Masyarakat, Universitas Airlangga. Surabaya.

Andraeni, Ni Nyoman Novitasari, (2005). Pengaruh Stres Kerja Terhadap Motivasi Kerja Dan Kinerja Karyawan PT. H.M. Sampoerna Tbk Surabaya, Tesis, Program Pasca Sarjana Universitas Airlangga Surabaya

As'ad, M. (2004). Psikologi Industri, Seri Umum. Sumber Daya Manusia. Edisi 4. Yogyakarta: Liberty. perusahaan perlu untuk memperbaiki kerjasama antar sesama rekan kerja dan atasan. Pengendalian stres kerja karyawan dilakukan dengan cara menyesuaikan pekerjaan karyawan dengan karakteristik tugas karyawan. Dan untuk menjaga lingkungan kerja pada perusahaan dilakukan dengan cara memberikan kepercayaan kepada karyawan agar dapat bertanggung jawab atas pekerjaan yang diberikan kepadanya.

Bernardin \& Russel. (2006). Manajemen Sumber Daya Manusia. Diterjemahkan oleh Bambang Sukoco. Bandung: Armico

Ghozali, Imam, (2006). Aplikai Analisis Multivarite dengan SPSS. Badan Penerbit Universitas Diponegoro. Semarang

Hasan, Aziz Adam. (2012). Pengaruh Faktor Individu dan LIingkungan Kerja Terhadap Kinerja Karyawan. Media Pressindo. Yogyakarta.

$$
\begin{array}{llr}
\text { Hasibuan, } & \text { Malayu. } & \text { (2003). } \\
\text { Manajemen } & \text { Sumber } & \text { Daya } \\
\text { Manusia. } & \text { Jakarta: } & \text { Bumi } \\
\text { Aksara. } & &
\end{array}
$$

Hertanto, Eko. (2011). Pengaruh Stressor, Kepuasan Kerja dan Lingkungan kerja Terhadap Kinerja Karyawan pada PT. Putera Dharma Industri Pulo Gadung, Jakarta Timur. Fakultas Ekonomi Universitas 
Pembangunan Nasional. Yogyakarta

Mangkunegara, Anwar Prabu (2006). Evaluasi Kinerja Sumber Daya Manusia. Jakarta: Refika Aditama

Mardiana, T. \& Muafi. (2004). Studi empiris pengaruh stressor terhadap kinerja. Jurnal Siasat Bisnis, 1 (6), 26-40.

Munandar, Ashar Sunyoto . (2008). Psikologi Industri dan Organisasi. Jakarta : UI Press Sadili. 2009. Manajemen Sumber Daya Manusia. Yogyakarta : Pustaka Pelajar.

Nur, Saina, (2013). Konflik, Stres Kerja dan Kepuasan Kerja Pengaruhnya Terhadap Kinerja Pegawai Pada Universitas Khairun Ternate. Jurnal Ekonomi Manajemen Bisnis. 1(3). 739-749

Primayanti, Atika, (2013). Pengaruh Faktor Individu dan Lingkungan Kerja terhadap Kinerja Karyawan Bagian Akuntansi dan Keuangan Bank BPR di Tanjungpinang. Program Studi Akuntansi, Fakultas Ekonomi. Universitas Maritim Raja Ali Haji.

Robbins, S. P. (2006).Perilaku Organisasi (alih bahasa Drs. Benjamin Molan), Edisi Bahasa Indonesia, Klaten: PT Intan Sejati.

Sasono, Eko. (2004). Mengelola Stres Kerja. Jurnal Fokus Ekonomi. III (2).

Septianto, Dwi. (2010). Pengaruh Lingkungan Kerja dan Stres
Kerja Terhadap Kinerja Karyawan (Studi pada PT. Pataya Raya Semarang). Fakultas Ekonomi Universitas Diponegoro. Semarang.

Sugiyono, (2011). Metode Penelitian Administrasi. Bandung. PT. Alfabeta.

Sutrisno, H. Edy, (2009). Pengaruh Budaya Organisasi, Stres Kerja dan Komitmen terhadap Kinerja Karyawan CV. Bintang Karya Putra di Surabaya. Ekuitas 14 (4).

Yusianto, (2008). Analisis Pengaruh Stres Kerja Terhadap Prestasi Kerja Staf Pengajar. Program Pasca Sarjana Magister Teknik Industri Universitas Islam Indonesia Yogyakarta. 